\title{
Field Evaluation of Populus deltoides Bartr. ex Marsh. at Two Sites in Indo-gangetic Plains of India
}

\author{
By G. P. S. Dhillon ${ }^{1)}$, Avtar Singh, Pritpal Singh and D. S. Sidhu \\ Department of Forestry \& Natural Resources, Punjab Agricultural University, Ludhiana
}

(Received $22^{\text {th }}$ October 2008)

\begin{abstract}
Results from clonal trials of Populus deltoides conducted in two distinct agroclimatic regions of Punjab in northwestern India are reported and discussed. Sixteen clones were evaluated at Hambran and Bathinda where commonly grown clone 'G-48' was considered as control. Significant differences among clones $(\mathrm{P}<0.001)$ were observed for diameter at breast height $(\mathrm{DBH})$, tree height and volume at the age of four and six years under both the site conditions. Clone 'L-48' ranked first for volume at six year age at both sites and was followed by clone 'Ranikhet'. The respective superiority for volume of these clones over control was 44.8 and 23.2 per cent at Hambran and 72.5 and 30.7 per cent at Bathinda. All growth traits registered significantly higher values at Hambran in comparison to those at Bathinda. Clone $\mathrm{x}$ site interaction was also significant $(\mathrm{P}<0.001)$. The clones 'L-168', '154/86', 'Solan-z' and '170/88' experienced huge fluctuation in ranking between sites for volume at 6-year age. The DBH and height showed significant and positive correlation with each other and with tree volume at all the age combinations. The clonal mean heritability was quite high both at Hambran (0.73-0.86) and Bathinda (0.80-0.95). The genetic advance were the highest for volume (33.34-64.26\%) and the lowest $(10.65-22.79 \%)$ in case of height.
\end{abstract}

Key words: clonal heritability, clone-site interaction, genetic correlation, clonal selection.

\section{Introduction}

The natural forests of developing countries have been over-exploited since the middle of the last century for meeting the needs of burgeoning human and cattle population and for clearing of green land for farming. The gap between demand and supply for wood based products is widening in India, as the productivity of natural forests is very low $\left(0.7 \mathrm{~m}^{3} / \mathrm{ha} / \mathrm{yr}\right)$ and the majority of the prevalent forests are degraded. The National Forest Policy of 1988 gave greater emphasis on the promotion of farm forestry to enhance wood productivity. Short rotation farm forestry tree species such as eucalypts, poplars, pines and subabul have drawn the attention of tree growers across India. Among these exotic tree species, Populus deltoides Bartr. ex Marsh., commonly known as 'poplar', is most extensively planted by farmers of north-western India. Its higher productivity (up to $48 \mathrm{~m}^{3} / \mathrm{ha} / \mathrm{yr}$ ), short rotation (5-7 years), straight stem and deciduous nature make it more compatible in agroforestry systems (SIDHu and DHILlon, 2007). The soft,

$\overline{{ }^{1} \text { Corresponding author. E-Mail: dhillongps1@rediffmail.com }}$ attractive, strong and easily workable wood of this species is suitable for manufacturing of matches, furniture, packing cases, plywood, sports goods, pulp and paper, rayon, fiberboard and pencils. After its introduction in 1950s in India (MATHUR and SHARMA, 1983), poplar was initially adopted by only a few innovative farmers of North-Western India (in eighties of the foregone century) for diversification from traditional ricewheat crop rotation. However, its highly remunerative returns in comparison to rice-wheat rotation attracted large numbers of farmers towards poplar cultivation as a block plantation or on the farm boundaries. Poplar based agroforestry plantations in the states of Punjab, Haryana, Uttar Pradesh and Uttrakhand occupy an area equivalent to 60,000 ha of pure plantations of this species (CHANDRA, 2001). Commercial planting of $P$. deltoides in India has so far relied on the use of few clones of poplar viz. 'G-3', 'G-48', 'D-121', 'ST-67', 'S $\mathrm{S}_{7} \mathrm{C}_{4}$ ' and ' $\mathrm{S}_{7} \mathrm{C}_{8}$ ' (Chaturvedi, 1992). About 90 percent of the poplar plantations in India are based on clones 'G-48', 'G-3' and ' $\mathrm{S}_{7} \mathrm{C}_{15}$ ' (Kumar et al., 1999). In the recent past, the highly narrow genetic base of these poplar plantations has resulted in the outbreak of leaf defoliators, bark eating caterpillar, stem borers, etc. in this region (SINGH et al., 2004).

Punjab Agricultural University (PAU) Ludhiana initiated the introduction and evaluation of poplar clones in late $1980 \mathrm{~s}$, as poplar does not bear catkins in this region. Ninety seven clones were introduced during February 1996 from four institutes of India viz. WIMCO Seedling Ltd., Forest Research Institute, Dehra Dun, Uttrakhand State Forest Department and University of Horticulture \& Forestry, Nauni. Based on initial screening for adaptability, 63 clones were tested under nursery conditions for two years and promising clones were short listed for the field evaluation. The selected clones were tested at two variable sites under field conditions to assess the variation in growth traits among clones at rotation age and to identify site specific clones for enhancing the productivity.

\section{Materials and Methods}

\section{Study area}

Clonal trials were conducted in two agroclimatic zones of the state. In the central-plain region, the study was conducted on a farmer's field at Village Hambran on the left bank of river Satluj which is $15 \mathrm{~km}$ from the main campus of Punjab Agricultural University (PAU), Ludhiana. The site suits well for the optimum growth of 
Table 1. - The location and climatic conditions of the study sites.

\begin{tabular}{|c|c|c|c|}
\hline \multicolumn{2}{|c|}{ Climatic/edaphic feature } & Site 1 (Hambran) & Site 2 (Bathinda) \\
\hline \multicolumn{2}{|l|}{ Agro-climatic zone } & Central-plain-region & Semi-arid region \\
\hline \multicolumn{2}{|c|}{ Latitude, longitude and altitude } & $\begin{array}{l}30^{\circ} 54^{\prime} \mathrm{N}, \quad 75^{\circ} 52^{\prime} \mathrm{E}, \\
\text { and } 240 \mathrm{~m}\end{array}$ & $\begin{array}{l}30^{\circ} 17^{\prime} \mathrm{N}, 74^{\circ} 57^{\prime} \mathrm{E} \text { and } \\
211 \mathrm{~m}\end{array}$ \\
\hline \multicolumn{2}{|c|}{ Rainfall per annum } & $732 \mathrm{~mm}$ & $400 \mathrm{~mm}$ \\
\hline \multirow{3}{*}{$\begin{array}{l}\text { Soil Moisture } \\
\text { Index (June- } \\
\text { Sept. Weeks) }\end{array}$} & Wet humid & 12 & 0 \\
\hline & Humid dry & 1 & 6 \\
\hline & Dry arid & 4 & 11 \\
\hline \multirow[t]{2}{*}{$\begin{array}{l}\text { Underground } \\
\text { water }\end{array}$} & $\begin{array}{l}\text { Reservoir } \\
\text { depth (ft) }\end{array}$ & 20 & 100 \\
\hline & Quality & Good & Marginal \\
\hline \multicolumn{2}{|l|}{ Irrigation Source } & Tubewell & Canal \\
\hline \multicolumn{2}{|l|}{ Soil pH } & 8.2 & 8.6 \\
\hline \multicolumn{2}{|l|}{ Soil texture } & Sandy loam & $\begin{array}{l}\text { Loamy sand to sandy } \\
\text { loam }\end{array}$ \\
\hline
\end{tabular}

poplar with majority of agricultural fields in the vicinity having poplar plantations. The second trial was planted at the Experimental Farm of PAU at the Regional Research Station Bathinda. The climate in this region is semi-arid to arid with canal as the main source of irrigation. The climatic and edaphic conditions of sites are given in Table 1.

\section{Treatments and experimental design}

The clones used for the study were selected on basis of initial screening for two years at the nursery stage with respect to adaptability and tolerance to insects. At both the sites, 20 clones were planted and 16 clones were common. Seven clones (Ranikhet, Solan-1, 45, 200/85, 154/86, UFD-6400 and Solan-z) were introduced from University of Horticulture and Forestry, Nauni, India and another set of seven clones (L-127, L-17, L-47, L-168, L-57, L-170 and L-48) were procured from Uttrakhand State Forest Department Research Center, Lal Kuan (India). Clone '72/58' was obtained from Forest Research Institute, Dehra Dun. Clone 'G-48' (originated from Australia) which is most extensively planted in north-western India was used as a control at both sites. The ETP's (entire transplants, one year old rooted cuttings) of these clones, raised at nursery area of Department of Forestry \& Natural Resources, PAU, Ludhiana, were transported to the study sites during January 1999. The experiments were conducted following complete randomized block design with four replications and plot size of five trees. A boundary row of non-experimental plants was planted to check the border effect. The clones were randomized independently in each of the four blocks/replications with plot shape of five plants as row. The ETP's were planted at $5 \times 4 \mathrm{~m}$ spacing with planting depth of one meter. Uniform silvicultural practices of planting, fertilizer application, weeding and pruning (SIDHU et al., 1990) were applied to all trees of a trial throughout completion of the study. The frequency of irrigation at Bathinda was relatively less because of scanty canal supply for many weeks in a year, however the uniform life saving watering was applied to the trial during such periods.

\section{Data recording and statistical analyses}

The data on height and diameter at breast height $(\mathrm{DBH})$, measured at $1.37 \mathrm{~m}$ from ground surface, were recorded from individual trees during December every year. The growth parameters recorded at the age of four and six years are given in this paper. Volume per plant was worked out on the basis of the following equation developed by DHANDA and VERMA (2001) for this region.

$$
\mathrm{V}=0.00703+0.32223 * \mathrm{D}_{2} \mathrm{H},
$$

where V, D and H stands for volume $\left(\mathrm{m}^{3}\right), \mathrm{DBH}(\mathrm{m})$ and tree height $(\mathrm{m})$, respectively.

The data from both the trials were pooled and analyzed according to the following model $Y_{i j k l}=\mu+S_{i}+$ $\mathrm{B}_{\mathrm{j}(\mathrm{i})}+\mathrm{C}_{\mathrm{k}}+\mathrm{CS}_{\mathrm{ik}}+\mathrm{BC}_{\mathrm{j}(\mathrm{i}) \mathrm{k}}+\mathrm{e}_{\mathrm{ijkl}}$, where $\mathrm{Y}_{\mathrm{ijkl}}$ is the performance of $l$ th ramet of $k$ th clone growing in $j$ th block of $i$ th site; $\mu$ is overall mean of the both sites; $S_{i}$ is the effect of $i$ th test site $(\mathrm{i}=1,2) ; \mathrm{B}_{\mathrm{j}(\mathrm{i})}$ is the effect of $j$ th block within $i$ th site $(\mathrm{j}=1, \ldots 4) ; \mathrm{C}_{\mathrm{k}}$ is the effect of the $k$ th clone $(\mathrm{k}=1, \ldots 16) ; \mathrm{CS}_{\mathrm{ik}}$ is the interactive effect of $k$ th clone and $i$ th site; $\mathrm{BC}_{\mathrm{j}(\mathrm{i}) \mathrm{k}}$ is the interactive effect of $k$ th clone and $j$ th block (within $i$ th site) and $\mathrm{e}_{\mathrm{ijkl}}$ is the random error associated with ramets within plot $(1=1, \ldots 5)$. All the factors were considered as random. The data from individual sites were also analyzed using the same model but without site and its interaction with clone.

\section{Estimation of heritability and coefficients of variation}

In case of the individual site analysis the broad sense heritability on individual tree basis was worked out as$\mathrm{H}^{2}{ }_{\mathrm{i}}=\sigma^{2}{ }_{\mathrm{c}} / \sigma^{2}{ }_{\mathrm{P}}$, where $\mathrm{H}^{2}$ i denotes heritability on an individual tree basis which is relevant to estimation of gains from selection of best individual ramets from a particular clonal trial, $\sigma^{2}{ }_{\mathrm{c}}$ variance due to clonal effects (i.e. including additive and non-additive genetic variances) for the particular trial and $\sigma_{\mathrm{P}}^{2}$ phenotypic variance among ramets in the trial. $\sigma_{\mathrm{P}}^{2}$ is calculated as $\sigma_{\mathrm{P}}^{2}=\sigma^{2}{ }_{\mathrm{c}}+$ $\sigma^{2}{ }_{c b}+\sigma^{2}{ }_{w}$, where $\sigma_{c b}^{2}$ represents variance due to cloneblock interaction and $\sigma^{2}$ within-plot error.

The broad-sense heritability relevant to estimating genetic gain from selection of best clones is the "clonal heritability" (denoted $\mathrm{H}^{2}{ }_{\mathrm{c}}$ ) which was calculated following equation suggested by LAMBETH et al. (1994).

$$
\mathrm{H}^{2} \mathrm{c}=\frac{\sigma_{\mathrm{c}}^{2}}{k_{2} \sigma_{\mathrm{d}}^{2} / k_{2}+\left(k_{1} \sigma_{\mathrm{bc}}^{2} / k_{1}\right)+\sigma_{\mathrm{e}}^{2} / k_{2}}
$$

Where $k_{1}$ is coefficient associated with the variance due to block $x$ clone interaction $\left(\sigma^{2}{ }_{\text {bc }}\right)$ and $k_{2}$ is the coeffi- 
cient associated with the variance due to clonal variation $\left(\sigma^{2}{ }_{c}\right)$.

Other genetic parameters like genetic coefficient of variation (GCV), phenotypic coefficient of variation (PCV) was worked out following JoHNSON et al. (1955).

On basis of analysis across sites, clonal mean heritability $\left(\mathrm{H}^{2} \mathrm{c}_{\mathrm{P}}\right)$ was calculated using the following equation:

$$
\mathrm{H}^{2} \mathrm{c}_{\mathrm{P}}=\frac{\sigma_{\mathrm{c}}^{2}}{\left.k_{5} \sigma_{d}^{2} k_{5}+k_{3} \sigma_{\mathrm{cs}}^{2} k_{5}+k_{4} \sigma_{b c}^{2} k_{5}\right)+\sigma_{\mathrm{e}}^{2} / k_{5}}
$$

where $\sigma_{c}^{2}, \sigma_{c s}^{2}, \sigma_{b c}^{2}$ and $\sigma^{2}$ e represents variance due to clones, clone-site interaction, clone-block interaction and within-plot error. $k_{3}$ is coefficient associated with the variance due to location $\mathrm{x}$ clone interaction $\left(\sigma^{2}{ }_{\mathrm{cs}}\right), k_{4}$ is the coefficient associated with the variance due to clone $\mathrm{x}$ block interaction and $k_{5}$ is the coefficient associated with the variance due to clonal variation $\left(\sigma_{c}^{2}\right)$ and standard error for clonal repeatability was worked following BECKER (1992).

\section{Estimation of genetic correlation among traits and Type B genetic correlations}

Genetic correlation $\left(\mathrm{r}_{\mathrm{Gxy}}\right)$ between traits $\mathrm{x}$ and $\mathrm{y}$ on same site was worked out using following expression

$$
\mathrm{r}_{\mathrm{Gxy}}=\mathrm{COV}_{\mathrm{Cxy}} / \sqrt{ }\left(\sigma_{\mathrm{Cx}}^{2} \cdot \sigma_{\mathrm{Cy}}^{2}\right) \text {, }
$$

where $\mathrm{COV}_{\mathrm{Cxy}}$ is clonal covariance between traits $\mathrm{x}$ and $y, \sigma_{C x}^{2}$ and $\sigma_{C y}^{2}$ are variance due to clonal effects for traits $\mathrm{x}$ and $\mathrm{y}$, respectively.

Type B genetic correlations $\left(r_{B}\right)$ between same traits at different sites were worked out according to BURDON (1977).

$$
\mathrm{r}_{\mathrm{B}}=\mathrm{r}_{\mathrm{xy}} / \mathrm{H}_{\mathrm{c}(\mathrm{x})} \cdot \mathrm{H}_{\mathrm{c}(\mathrm{y})}
$$

where $r_{x y}$ is the phenotypic correlation of clonal means and $\mathrm{H}_{\mathrm{c}(\mathrm{x})}$ and $\mathrm{H}_{\mathrm{c}(\mathrm{y})}$ are square roots of clonal mean heritabilities at each environment estimated from within site data analysis.

Type B genetic correlation $\left(r_{B}\right)$ is the genetic correlation between the same trait expressed on two different sites and essentially is a measure of $\mathrm{G} \times \mathrm{E}$ interaction $\left(0 \leq \mathrm{r}_{\mathrm{B}} \leq 1\right)$ and $\mathrm{r}_{\mathrm{B}} \approx 1$ indicates no $\mathrm{G} \times \mathrm{E}$ variance.

\section{Working out genetic advance and correlated response}

Genetic advance $(\Delta \mathrm{G})$ as per cent of mean from clonal selections in character y were estimated as

$$
\Delta \mathrm{G}=\left(\mathrm{i} * \mathrm{H}_{\mathrm{c}}^{2} * \sigma_{\mathrm{P}} / \overline{\mathrm{y}}\right) * 100
$$

where $\mathrm{i}$ is selection intensity $(1.80$, selecting best $5 \%$ clones), $\mathrm{H}^{2}{ }_{\mathrm{c}}$ is clonal mean heritability, $\sigma_{\mathrm{P}}$ is phenotypic standard deviation and $\bar{y}$ is general mean of the character.

The correlated response $\mathrm{CR}_{\mathrm{y}}$ (\% of mean) in desired character y brought about from the selection based on a secondary character $\mathrm{x}$ was calculated according to following expression FALCONER (1989)

$$
\mathrm{CR}_{\mathrm{y}}=\left[\left(\mathrm{i} \cdot \mathrm{H}_{\mathrm{Cx}} \cdot \mathrm{H}_{\mathrm{Cy}} \cdot \mathrm{r}_{\mathrm{Gxy}} \cdot \sigma_{\mathrm{Py}}\right) / \overline{\mathrm{y}}\right] * 100,
$$

where $\mathrm{i}$ is selection intensity (1.64, selecting best $10 \%$ clones), $\mathrm{H}_{\mathrm{Cx}}$ and $\mathrm{H}_{\mathrm{Cy}}$ are clonal heritabilities for trait $\mathrm{x}$ and $\mathrm{y}, \mathrm{r}_{\mathrm{Gxy}}$ is genetic correlation between trait $\mathrm{x}$ and $\mathrm{y}$, $\sigma_{\mathrm{P}}$ is phenotypic standard deviation and $\overline{\mathrm{y}}$ is general mean of the character.

\section{Results}

\section{Clonal variation for growth traits}

The analysis of variance indicated that clonal differences were found to be highly significant $(\mathrm{P}<0.001)$ for diameter at breast height $(\mathrm{DBH})$, tree height and volume per tree at both the sites at the age of 4 and 6 year (Table 2 and 3). The pooled analysis across sites also revealed significant differences $(\mathrm{P}<0.001)$ among clones and between sites at both the ages for all the three traits (Table 4). At Hambran, Clone '154/86' registered the maximum DBH at age 4 and was statistically at par with clones 'L-48' and 'Ranikhet'. Clone 'L-57' was significantly superior to all others for tree height at age 4 at the same site. At age six, clone 'L-48' registered statistically superior DBH and was followed by clones 'Ranikhet' and 'L-47'. Five other clones recorded statistically higher values than control (G-48). For tree height, only 'L-48' was superior to control. Clone 'Solan-1' attained the bottom rank at Hambran for both the traits and ages. Clones 'L-48' attained top ranking for $\mathrm{DBH}$ and height at Bathinda at both ages, whereas, the lowest values were recorded for ' $72 / 58$ '.

The volume per tree at 4 year age ranged from 0.0907 to $0.1741 \mathrm{~m}^{3}$ and 0.0217 to $0.0971 \mathrm{~m}^{3}$ at Hambran and Bathinda, respectively (Table 3). At former site, the top ranking was attained by 'L-48' which was at par with four other clones. 'L-48' was significantly superior to all other clones at Bathinda and was followed by 'L-47', 'L168 ' and 'Ranikhet'. 'L-48' maintained its top ranking at the both sites even at the age of 6-year and was statistically superior to others. Five other clones had higher volume than that of the control at Hambran. Like DBH and tree height, the lowest volume was recorded for 'Solan-1' at Hambran and '72/58' at Bathinda.

All the growth traits recorded at Hambran were significantly higher than their respective values at Bathinda at both the ages. The mean volume per tree after age 6 at Hambran $\left(0.2506 \mathrm{~m}^{3}\right)$ was almost double than that $\left(0.1319 \mathrm{~m}^{3}\right)$ at Bathinda. The clone $\mathrm{x}$ site interaction was also significant $(\mathrm{P}<0.001)$ at both the ages for all three traits. Clones 'L-48', 'Ranikhet', '45', 'L-47', 'L-127' and 'L-17' remained almost stable across sites for all the traits, whereas, '154/86', 'L-168' and 'L-170' experienced huge changes in ranks between sites. Type B genetic correlation, another measure of $\mathrm{g} x$ e interaction, was the minimum (0.25) for $\mathrm{DBH}$ and the maximum value (0.51) was for height at four year age (Table 4). All the values increased at age 6 and ranged from 0.51 for $\mathrm{DBH}$ to 0.67 for volume. This indicated moderate clone-site interaction.

\section{Genetic parameters and correlations}

On the basis of individual site analysis, all genetic parameters were relatively higher at Bathinda than 
Table 2. - Mean diameter at breast height (DBH), tree height and genetic parameters of poplar clones planted at two sites.

\begin{tabular}{|c|c|c|c|c|c|c|c|c|}
\hline \multirow[t]{2}{*}{ Clone } & \multicolumn{4}{|c|}{ Hambran } & \multicolumn{4}{|c|}{ Bathinda } \\
\hline & DBH 4 yr & $\begin{array}{ll}\text { Height } & 4 \\
\text { yr } & \end{array}$ & DBH 6 yr & $\begin{array}{ll}\begin{array}{l}\text { Height } \\
\text { yr }\end{array} & 6 \\
\end{array}$ & $\mathrm{DBH} 4 \mathrm{yr}$ & Height $4 \mathrm{yr}$ & DBH 6 yr & Height 6 yr \\
\hline Ranikhet & $18.23^{\text {tb }}$ & $15.46^{6}$ & $21.70^{6}$ & $19.26^{\mathrm{bc}}$ & $12.53^{\text {cd }}$ & $11.67^{\mathrm{ef}}$ & $17.80^{6}$ & $16.05^{\mathrm{c}}$ \\
\hline Solan-1 & $14.18^{\mathrm{g}}$ & $12.69^{i}$ & $17.28^{k}$ & $16.23^{1}$ & $11.24^{\text {gh }}$ & $10.99^{\mathrm{g}}$ & 14.48 & $14.54^{\mathrm{g}}$ \\
\hline 45 & $15.55^{\mathrm{f}}$ & $14.53^{\mathrm{h}}$ & $18.48^{j}$ & $18.09^{8}$ & $10.86^{i}$ & $10.85^{\text {sh }}$ & $14.70^{13}$ & $14.02^{2}$ \\
\hline $200 / 85$ & $18.13^{b}$ & $14.83^{\mathrm{fg}}$ & $20.15^{\text {cde }}$ & $19.06^{\mathrm{cd}}$ & $11.87^{\text {ef }}$ & $11.52^{\mathrm{f}}$ & $16.30^{\mathrm{f}}$ & $14.98^{f}$ \\
\hline $154 / 86$ & $18.50^{\mathrm{a}}$ & $15.03^{e}$ & $20.47^{\mathrm{c}}$ & $18.88^{\text {de }}$ & $10.90^{\mathrm{hi}}$ & $10.63^{\mathrm{h}}$ & $14.05^{\mathrm{k}}$ & $14.43^{\text {gh }}$ \\
\hline UFD-6400 & $16.88^{\mathrm{d}}$ & $14.27^{\mathrm{i}}$ & $19.80^{\mathrm{cfg}}$ & $18.46^{\mathrm{f}}$ & $12.22^{\mathrm{dc}}$ & $11.51^{\mathrm{f}}$ & $16.75^{\mathrm{de}}$ & $15.65^{d}$ \\
\hline Solan-z & $17.10^{\text {cl }}$ & $14.73^{\mathrm{g}}$ & $19.80^{\mathrm{efg} g}$ & $17.60^{h}$ & $12.18^{\text {de }}$ & $11.58^{f}$ & $16.28^{f}$ & $15.37^{\mathrm{e}}$ \\
\hline $72 / 58$ & $17.00^{\mathrm{d}}$ & $14.45^{\mathrm{h}}$ & $19.89^{\mathrm{ef}}$ & $17.67^{\mathrm{h}}$ & $7.43^{\mathrm{k}}$ & $7.51^{\mathrm{j}}$ & $9.70^{\mathrm{m}}$ & $10.06^{j}$ \\
\hline $\mathrm{L}-127$ & $17.30^{\mathrm{c}}$ & $15.23^{\text {cd }}$ & $19.98^{\mathrm{de}}$ & $18.49^{f}$ & $10.98^{\mathrm{hi}}$ & $12.68^{\mathrm{bc}}$ & $15.73^{g}$ & $15.74^{\mathrm{d}}$ \\
\hline L-17 & $16.85^{\mathrm{dc}}$ & $14.86^{\mathrm{fg}}$ & $19.55^{\text {fgh }}$ & $17.98^{\mathrm{g}}$ & $10.86^{i}$ & $11.08^{g}$ & $15.00^{h}$ & $14.30^{\text {gh }}$ \\
\hline $\mathrm{L}-47$ & $18.20^{b}$ & $15.22^{\mathrm{d}}$ & $21.35^{b}$ & $18.49^{\mathrm{f}}$ & $12.70^{b c}$ & $12.98^{6}$ & $17.10^{\mathrm{c}}$ & $17.13^{b}$ \\
\hline L-168 & $17.05^{\text {cd }}$ & $14.92^{\mathrm{ef}}$ & $18.98^{i}$ & $18.78^{\mathrm{e}}$ & $12.91^{b}$ & $11.51^{\mathrm{f}}$ & $16.93^{\mathrm{cd}}$ & $15.48^{\text {de }}$ \\
\hline L-57 & $16.58^{\circ}$ & $16.08^{\mathrm{a}}$ & $19.23^{\mathrm{hi}}$ & $19.38^{b}$ & $11.57^{\mathrm{fg}}$ & $12.33^{\text {ad }}$ & $14.85^{\mathrm{hi}}$ & $15.64^{\text {de }}$ \\
\hline $\mathrm{L}-170$ & $18.08^{b}$ & $15.50^{6}$ & $20.30^{\mathrm{cd}}$ & $19.48^{b}$ & $9.82^{\mathrm{J}}$ & $10.98^{\text {gh }}$ & $13.03^{1}$ & $14.20^{\mathrm{hi1}}$ \\
\hline L-48 & $18.25^{\text {ab }}$ & $15.42^{b}$ & $22.83^{\mathrm{a}}$ & $20.53^{\mathrm{a}}$ & $13.93^{4}$ & $13.90^{\mathrm{a}}$ & $19.28^{\mathrm{a}}$ & $17.68^{\mathrm{al}}$ \\
\hline G-48 (control) & $17.28^{\mathrm{c}}$ & $15.37^{\mathrm{bc}}$ & $19.48^{\mathrm{gh}}$ & $19.24^{\mathrm{bc}}$ & $11.99^{\circ}$ & $11.98^{\mathrm{dc}}$ & $16.53^{\mathrm{cf}}$ & $16.29^{\mathrm{C}}$ \\
\hline Mean \pm S.E. & $17.20 \pm 0.17$ & $14.91 \pm 0.07$ & $19.95 \pm 0.12$ & $18.60 \pm 0.08$ & $11.50 \pm 0.21$ & $11.50 \pm 0.21$ & $15.53 \pm 0.15$ & $15.09 \pm 0.11$ \\
\hline M.S. ${ }_{\mathrm{c}}$ & $25.39 * * *$ & $11.24 * * *$ & $33.25^{* * *}$ & $19.25^{* * *}$ & $43.55 * * *$ & $37.47 * * *$ & $98.79 * * *$ & $56.75 * * *$ \\
\hline M.S..$_{e}$ & 1.84 & 1.01 & 2.66 & 0.953 & 1.67 & 1.10 & 3.79 & 1.30 \\
\hline $\mathrm{H}_{\mathrm{i}}^{2}$ & 0.33 & 0.23 & 0.26 & 0.33 & 0.42 & 0.41 & 0.54 & 0.56 \\
\hline $\mathrm{H}_{\mathrm{c}}^{2}$ & 0.85 & 0.73 & 0.76 & 0.79 & 0.85 & 0.83 & 0.95 & 0.92 \\
\hline PCV (\%) & 10.58 & 9.05 & 11.19 & 8.19 & 18.39 & 16.83 & 18.96 & 14.32 \\
\hline GCV(\%) & 6.05 & 4.31 & 5.65 & 4.70 & 11.86 & 10.84 & 13.99 & 10.75 \\
\hline $\mathrm{GA}(\%$ of mean $)$ & 14.77 & 10.89 & 14.01 & 10.65 & 25.75 & 22.79 & 29.68 & 21.49 \\
\hline
\end{tabular}

Means followed by same letter do not differ $(\mathrm{P}<0.05)$ by LSD test. $* * *$ indicate significance at $\mathrm{P}<0.001$.

M.S.c is mean sum of squares for clones; M.S.e is mean sum of squares for error; $\mathrm{H}^{2}{ }_{\mathrm{i}}$ is individual tree heritability; $\mathrm{H}^{2}{ }_{\mathrm{c}}$ is clonal heritability and GA is genetic advance as per cent of mean.

Table 3. - Mean volume per tree and genetic parameters at two ages for poplar clones planted at two sites.

\begin{tabular}{|c|c|c|c|c|c|c|c|c|}
\hline \multirow[t]{3}{*}{ Clone } & \multicolumn{4}{|c|}{ Age 4 years } & \multicolumn{4}{|c|}{ Age 6 years } \\
\hline & \multicolumn{2}{|c|}{ Hambran } & \multicolumn{2}{|c|}{ Bathinda } & \multicolumn{2}{|c|}{ Hambran } & \multicolumn{2}{|c|}{ Bathinda } \\
\hline & Mean $\left(\mathrm{m}^{3}\right)$ & Rank & $\operatorname{Mean}\left(\mathrm{m}^{3}\right)$ & Rank & $\operatorname{Mean}\left(\mathrm{m}^{3}\right)$ & Rank & Mean $\left(m^{3}\right)$ & Rank \\
\hline Ranikhet & $0.1728^{\mathrm{a}}$ & 3 & $0.0681^{\mathrm{cd}}$ & 4 & $0.3012^{b}$ & 2 & $0.1724^{b}$ & 2 \\
\hline Solan-1 & $0.0907^{1}$ & 16 & $0.0539^{\mathrm{hi}}$ & 11 & $0.1658^{\mathrm{k}}$ & 16 & $0.1089^{i}$ & 13 \\
\hline 45 & $0.1210^{\mathrm{h}}$ & 15 & $0.0533^{\mathrm{hi}}$ & 14 & $0.2084^{i}$ & 15 & $0.1081^{i}$ & 12 \\
\hline $200 / 85$ & $0.1653^{b}$ & 6 & $0.0599^{\mathrm{fg}}$ & 9 & $0.2583^{\circ}$ & 6 & $0.1367^{\mathrm{fg}}$ & 8 \\
\hline $154 / 86$ & $0.1740^{\mathrm{a}}$ & 2 & $0.0499^{i}$ & 13 & $0.2688^{\text {de }}$ & 5 & $0.1020^{j}$ & 14 \\
\hline UFD- 6400 & $0.1391^{g}$ & 14 & $0.0634^{\mathrm{ef}}$ & 7 & $0.2426^{\text {fog }}$ & 10 & $0.1448^{\mathrm{de}}$ & 6 \\
\hline Solan-z & $0.1470^{\text {cf }}$ & 11 & $0.0641^{\mathrm{def}}$ & 6 & $0.2320^{\text {ghi }}$ & 12 & $0.1413^{\text {cf }}$ & 7 \\
\hline $72 / 58$ & $0.1431^{\mathrm{fg}}$ & 13 & $0.0217^{k}$ & 16 & $0.2371^{\text {felii }}$ & 11 & $0.0400^{\perp}$ & 16 \\
\hline L-127 & $0.1545^{\text {cd }}$ & 8 & $0.0566^{\text {gh }}$ & 10 & $0.2465^{f}$ & 7 & $0.1343^{\circ}$ & 9 \\
\hline L-17 & $0.1439^{\mathrm{fg}}$ & 12 & $0.0509^{i}$ & 12 & $0.2302^{\mathrm{hi}}$ & 13 & $0.1123^{i}$ & 11 \\
\hline L-47 & $0.1701^{\mathrm{ab}}$ & 5 & $0.0760^{b}$ & 2 & $0.2827^{\circ}$ & 3 & $0.1720^{b}$ & 3 \\
\hline L-168 & $0.1502^{\mathrm{de}}$ & 10 & $0.0702^{c}$ & 3 & $0.2274^{i}$ & 14 & $0.1526^{c}$ & 5 \\
\hline $\mathrm{L}-57$ & $0.1510^{\text {de }}$ & 9 & $0.0616^{\mathrm{ef}}$ & 8 & $0.2393^{\text {rgh }}$ & 9 & $0.1208^{\mathrm{h}}$ & 10 \\
\hline $\mathrm{L}-170$ & $0.1738^{\mathrm{a}}$ & 4 & $0.0421^{j}$ & 15 & $0.2715^{\mathrm{cid}}$ & 4 & $0.0876^{k}$ & 15 \\
\hline L-48 & $0.1741^{\mathrm{a}}$ & 1 & $0.0971^{\mathrm{a}}$ & 1 & $0.3540^{\mathrm{a}}$ & 1 & $0.2275^{a}$ & 1 \\
\hline G-48 (control) & $0.1569^{c}$ & 7 & $0.0655^{\mathrm{de}}$ & 5 & $0.2444^{f}$ & 8 & $0.1484^{\text {cd }}$ & 4 \\
\hline Mean \pm S.E. & $0.1517 \pm 0.0020$ & & $0.0596 \pm 0.0014$ & & $0.2506 \pm 0.0037$ & & $0.1319 \pm 0.0030$ & \\
\hline M.S..$_{c}$ & $0.00996^{* * * *}$ & & $0.0052 * * *$ & & $0.03441^{* * *}$ & & $0.0359 * * *$ & \\
\hline M.S.c & 0.00074 & & 0.00025 & & 0.0022 & & 0.00111 & \\
\hline $\mathrm{H}_{\mathrm{i}}^{2}$ & 0.33 & & 0.35 & & 0.31 & & 0.58 & \\
\hline $\mathrm{H}_{\mathrm{c}}^{2}$ & 0.86 & & 0.81 & & 0.80 & & 0.95 & \\
\hline PCV (\%) & 23.75 & & 41.21 & & 26.75 & & 41.25 & \\
\hline $\mathrm{GCV}(\%)$ & 13.63 & & 24.42 & & 14.79 & & 31.34 & \\
\hline $\begin{array}{l}\text { Genetic advance } \\
\text { (\% of mean) }\end{array}$ & 33.34 & & 54.88 & & 35.09 & & 64.26 & \\
\hline
\end{tabular}

Means followed by same letter do not differ $(\mathrm{P}<0.05)$ by LSD test. $* * *$ indicate significance at $\mathrm{P}<0.001$.

M.S.c is mean sum of squares for clones, M.S.e is mean sum of squares for error. $\mathrm{H}^{2}{ }_{\mathrm{i}}$ is individual tree heritability, $\mathrm{H}^{2}$ is clonal heritability. 
Table 4. - Analysis of variance, variance components and genetic parameters for various growth traits of poplar clones based on pooled analysis across sites.

\begin{tabular}{|c|c|c|c|c|c|}
\hline Trait & Source & $\begin{array}{l}\text { Mean Sum } \\
\text { of squares }\end{array}$ & $\mathrm{H}^{2}{ }_{\mathrm{C}}$ & $\begin{array}{l}\text { Genetic } \\
\text { Advance } \\
(\% \text { of } \\
\text { mean) }\end{array}$ & $\mathrm{r}_{\mathrm{B}}$ \\
\hline DBH 4 yr & $\begin{array}{l}\text { Site } \\
\text { clone } \\
\text { Site x clone } \\
\text { error }\end{array}$ & $\begin{array}{l}5194.24 * * * \\
41.41 * * * \\
27.53 * * * \\
1.91\end{array}$ & $0.27 \pm 0.08$ & 6.59 & 0.25 \\
\hline Height 4 yr & $\begin{array}{l}\text { Site } \\
\text { clone } \\
\text { Site x clone } \\
\text { error }\end{array}$ & $\begin{array}{l}1883.76^{* * *} \\
32.54^{* * *} \\
16.18^{* * *} \\
1.25\end{array}$ & $0.39+0.09$ & 8.84 & 0.51 \\
\hline Volume 4 yr & $\begin{array}{l}\text { Site } \\
\text { clone } \\
\text { Site x clone } \\
\text { error } \\
\end{array}$ & \begin{tabular}{|l|}
$1.356 * * *$ \\
$0.00972 * * *$ \\
$0.00547^{* * * *}$ \\
0.000414 \\
\end{tabular} & $0.33 \pm 0.08$ & 13.11 & 0.35 \\
\hline DBH 6 yr & $\begin{array}{l}\text { Site } \\
\text { clone } \\
\text { Site x clone } \\
\text { error }\end{array}$ & $\begin{array}{l}3181.99^{* * *} \\
87.03^{* * * *} \\
43.68^{* * *} \\
3.35\end{array}$ & $0.45 \pm 0.09$ & 8.36 & 0.51 \\
\hline Height 6 yr & $\begin{array}{l}\text { Site } \\
\text { clone } \\
\text { Site x clone } \\
\text { error }\end{array}$ & $\begin{array}{l}2131.24 * * * \\
49.55^{* * *} \\
23.37 * * * \\
1.301\end{array}$ & $0.44 \pm 0.09$ & 8.66 & 0.56 \\
\hline Volume $6 \mathrm{yr}$ & $\begin{array}{l}\text { Site } \\
\text { clone } \\
\text { Site x clone } \\
\text { error }\end{array}$ & $\begin{array}{l}2.275^{* * * *} \\
0.0533 * * * \\
0.0158 * * * \\
0.00173\end{array}$ & $0.62 \pm 0.09$ & 23.94 & 0.67 \\
\hline
\end{tabular}

$\mathrm{H}^{2}{ }_{\mathrm{c}}$ is clonal mean heritability, $\mathrm{r}_{\mathrm{B}}$ is Type $\mathrm{B}$ genetic correlation. *** indicate significance at $\mathrm{P}<0.001$.

those at Hambran for both the ages and all the growth traits (Table 3). For any age, the phenotypic coefficients of variation (10.57 to $40.85 \%$ ) and genotypic coefficients of variation (6.05 to $30.89 \%$ ) were relatively higher for volume and the lowest values were for tree height. The genetic advance also followed similar trend with relatively higher values for volume both at Hambran (33.34 to $35.09 \%$ ) and Bathinda (54.88 to $64.26 \%$ ). The clonal mean heritability (on the basis of pooled analysis) was low for $\mathrm{DBH}$ and Height, and relatively higher values were observed for volume at both the ages (Table 4). It ranged from 0.27 for $\mathrm{DBH}$ at 4 year age to 0.62 for volume at age 6 . The heritability increased at higher age for all the growth traits. Genetic correlations between traits within each site are shown in Table 5. All the trait combination had significantly $(\mathrm{P}<0.001)$ positive correlation with one another. The correlated response (\% of mean) for volume at age 6 was quite high both at Hambran (26.3-32.6) and Bathinda (54.7-61.3) (Table 6).

\section{Discussion}

This study clearly indicated the potential for considerable improvement in growth traits of $P$. deltoides under Punjab conditions, as huge amount of variation among clones $(\mathrm{P}<0.001)$ exists at the two sites. Clones 'L-48', 'Ranikhet' and 'L-47' were found to be superior with respective volume superiority over check (G-48) of 44.8, 23.2 and 15.7 per cent at Hambran and 72.5, 30.7 and 30.4 per cent at Bathinda. The significant variation

Table 5. - Genetic correlation coefficients between various growth traits of poplar clones at two sites.

\begin{tabular}{|l|l|l|l|l|r|r|}
\hline & DBH 4 & DBH 6 & Height 4 & Height 6 & Volume 4 & Volume 6 \\
\hline DBH 4 & & $0.995^{* * *}$ & $0.889^{* * *}$ & $0.858^{* * *}$ & $0.996^{* * *}$ & $0.992^{* * *}$ \\
\hline DBH 6 & $0.999^{* * *}$ & & $0.804^{* * *}$ & $0.807^{* * *}$ & $0.965^{* * *}$ & $0.989^{* * *}$ \\
\hline Height 4 & $0.890^{* * *}$ & $0.930^{* * *}$ & & $0.963^{* * *}$ & $0.916^{* * *}$ & $0.858^{* * *}$ \\
\hline Height 6 & $0.994^{* * *}$ & $0.940^{* * *}$ & $0.999^{* *}$ & & $0.772^{* * *}$ & $0.872^{* * *}$ \\
\hline Volume 4 & $0.972^{* * *}$ & $0.998^{* * *}$ & $0.908^{* * *}$ & $0.981^{* * *}$ & & $0.998^{* * *}$ \\
\hline Volume 6 & $0.998^{* * *}$ & $0.980^{* * *}$ & $0.948^{* * *}$ & $0.933^{* * *}$ & $0.999^{* * *}$ &
\end{tabular}

*** denotes the significant at 0.1 per cent, respectively. Figures in above diagonal are for "Hambran" and in lower diagonal are for Bathinda. 
Table 6. - Correlated genetic advance (\% of mean) of height, DBH and volume at age 6 at two sites in responses to indirect selection.

\begin{tabular}{|l|c|c|c|c|c|c}
\hline \multirow{2}{*}{$\begin{array}{l}\text { Selection } \\
\text { aimed at }\end{array}$} & \multicolumn{3}{|c|}{ Hambran } & \multicolumn{3}{c}{ Bathinda } \\
\cline { 2 - 7 } & Height 6 & DBH 6 & Vol 6 & Height 6 & DBH 6 & Vol 6 \\
\hline Ht 4 & 9.9 & 11.1 & 28.7 & 19.0 & 24.2 & 54.7 \\
\hline Ht 6 & 10.8 & 11.6 & 30.7 & 20.3 & 25.5 & 57.6 \\
\hline DBH4 & 9.5 & 14.7 & 35.7 & 17.2 & 26.3 & 58.2 \\
\hline DBH 6 & 8.4 & 13.9 & 26.3 & 19.0 & 27.7 & 60.5 \\
\hline Vol 4 & 8.6 & 14.8 & 36.2 & 18.5 & 25.6 & 56.9 \\
\hline Vol 6 & 10.0 & 14.1 & 35.0 & 19.0 & 27.0 & 61.3 \\
\hline
\end{tabular}

among clones for all growth traits at both the site conditions in the present study may be attributed to their different genetic constitution. Similar significant clonal variation for diameter, height and volume under field conditions in $P$. deltoides was reported by earlier studies conducted under field conditions in India (ToKY et al., 1996; Singh et al., 2001; PuRI et al., 2002; SIDHU and DHILlon, 2007) and abroad (RANDALl and CoOPER, 1973, NELSON and TAUER, 1987).

The pooled analysis across sites indicated that the site means of all growth traits recorded at Hambran were significantly higher than respective values at Bathinda at both ages. The mean $\mathrm{DBH}$, height and volume superiority at Hambran after 6 year age was 28.5, 23.2 and 89.7 per cent. This may be attributed to favourable conditions at the former site like higher rainfall, better intensity and quality of irrigation and nearly neutral soils as described in Table 1. Similarly, significantly $(\mathrm{P}<0.05)$ higher growth of $P$. deltoides in central-plain region of Punjab was noticed by DHILLON (2004), than those in semi-arid region, while evaluating another set of clones.

The clone $\mathrm{x}$ site interaction was also significant $(\mathrm{P}<0.001)$ for all traits at both ages. The volume growth of clones ' $154 / 86$ ' and 'L-170) was comparatively better at Hambran, whereas clones 'UFD-6400' and 'L-168' were relatively superior at Bathinda. On the other hand, many clones ('Ranikhet', 'L-17', 'L-47', 'L-57' and 'L-48') were relatively stable clones after 6 year age at both sites with rank changes of $\leq 2$. The type $\mathrm{B}$ genetic correlations also indicated the moderate to high clone $\mathrm{x}$ site interaction for growth traits. The significance of clone $\mathrm{x}$ site interaction might be due to differential response of clones to the environments. Significant genotype $\mathrm{x}$ site interaction has been reported in young cottonwoods by RANDALL and COOPER (1973) for growth traits. RIEMENSCHNEIDER et al. (2001) also found that clone $\mathrm{x}$ location interaction in poplar was significant at age 3 year or higher. Many other findings on $P$. deltoides (RAndall and Mohn, 1969; Ares, 2002), Populus hybrid (Khalil, 1984; Zhang et al., 2003), and P. tomentosa (Gu et al., 1998) have also found significant clone-site interaction. Type B genetic correlations are commonly used to quantify the family/clone by site interactions in tree breeding programs (JOHNSON and BURDON, 1990; HodGe and WHITE, 1992).

The success or failure of any tree breeding program depends largely on extent of variability in the breeding population which is measured by different population parameters including phenotypic coefficient of variation (PCV), genotypic coefficient of variation (GCV) and heritability. In the present study, the genotypic coefficients were considerably lower than respective phenotypic coefficients. The PCV, GCV and genetic advance were relatively high for wood volume. The clonal mean heritability based on individual site analysis was quite high for all the traits (0.73-0.95). SinGH et al. (2001) while evaluating 50 clones of $P$. deltoides in Indo-gangetic plains of India reported the heritability for height, diameter and single tree volume to be 46.0, 54.7 and 70.4 per cent, respectively. However, low heritability for growth traits in the same species was found by WILCOX and FARMER (1967) and NELSON and TAUER (1987). Such variation may be due to the fact that heritability values are the estimates which often vary with age, population and site conditions.

Significant and positive correlation exists between all trait combinations in the present study which indicates that possible simultaneous improvement could be obtained while selecting for one or the other trait. Such relationships are useful as they provide a huge advantage to the breeder for improvement of these traits. Other studies (Foster, 1986; TEWARI et al., 1994) have also found positive and significant correlation between various growth traits of $P$. deltoides.

\section{Conclusion}

The study involving testing of 16 poplar clones at two sites revealed highly significant differences among clones which offer great scope for selection. Genetic correlations were significant between all trait combinations including those measured at four year age, therefore evaluation at an early age ( $4 \mathrm{yr}$ ) may be accurate. The clone-site interaction was moderate to high and all future genetic testing should be conducted over a range of sites.

\section{References}

ARES, A. (2002): Changes through time in traits of poplar clones in selection trials. New Forest 23 (2): 105-119.

BECKER, W. A. (1992): Manual of Quantitative Genetics. Academic Enterprises, Pullman, Wa. 189 p.

BuRDON, R. D. (1977): Genetic correlations as a concept for studying genotype-environment interaction in forest tree breeding. Silvae Genetica 26: 168-175.

ChANDRA, J. P. (2001): Scope of poplar cultivation. Indian Forester 127 (1): 51-60. 
Chaturvedi, A. N. (1992): Optimum rotation of harvest for poplars in farmlands under agroforestry. Indian Forester 118 (2): 81-88.

Dhanda, R. S. and R. K. Verma (2001): Timber volume and weight tables of farm-grown poplar (Populus deltoides Bartr. Ex Marsh.) in Punjab (India). Indian Forester 127 (1): 115-130.

Dhillon, G. P. S. (2004): Studies on genotype x environment interactions of Poplar (Populus deltoides) in Punjab. Ph.D thesis submitted to FRI, Dehradun.

FALCONER, D. S. (1989): Introduction to Quantitative Genetics. $3^{\text {rd }}$ Edition. Longman, London and John Wiley and Sons, New York.

Foster, G. S. (1986): Provenance variation of eastern cottonwood in the lower Mississippi valley. Silvae Genetica 35: 32-38.

Gu, W. C., F. GuI, Z. M. Yu, L. Q. Mu, C. L. Sun and J. H. ZHANG (1998): Study on selection and breeding for multiple use of a new variety of Populus tomentosa. Forest Research 11 (3): 299-305.

Hodge, G. R. and T. L. White (1992): Genetic parameter estimates for growth traits at different ages in slash pine and some implications for breeding. Silvae Genetica 41: 252-262.

Johnson, G. R. and R. D. Burdon (1990): Family-site interactions in Pinus radiata: Implications for progeny testing strategy and regionalized breeding in New Zealand. Silvae Genetica 39: 55-62.

Johnson, H.W., H. F. Robinson and R. E. Comstock (1955): Estimates of genetic and environmental variability in soybean. Agron Journal 47: 314-318.

KHALIL, M. A. K. (1984): The potential of poplar in Boreal region (i) survival and growth (ii) Genotypic stability and productive quality of clones. Silvae Genetica 33 (1): $1-11$.

Kumar, D., N. B. Singh, S. K. SRivastava, G. S. Rawat and D. Mohan (1999): Improvement of Populus deltoides in India I. Present Status. Indian Forester 125 (3): 245-263.

LAmbeth, C., M. Endo and J. Wright (1994): Genetic analysis of 16 clonal trials of Eucalyptus grandis and comparison to seedling checks. Forest Science. 40 (3): 397-411.

MathuR, R. S. and S. S. Sharma (1983): Poplars in India. Indian Forester 109 (9): 591-631.

Nelson, C. D. and C. G. TAUER (1987): Genetic variation in juvenile characters of Populus deltoides Bartr. from southern great plains. Silvae Genetica 36: 216-221.
PURI, S., S. L. SwAMI and A. K. JAISWAL (2002): Evaluation of Populus deltoides clones under nursery, field and agrisilviculture system in sub-humid tropics of central India. New Forest 23: 45-61.

RANDALL, W. K. and C. A. MoHN (1969): Clone site interaction of eastern cottonwood. Proc. of the Tenth Southern Conference on Forest Tree Improvement. p. 89-91.

RANDALL, W. K. and D. T. Cooper (1973): Predicted genotypic gain from cottonwood clonal test. Silvae Genetica 22: 165-167.

Riemenschneider, D. E., W. E. Berguson, D. I. Dickmann, R. B. Hall, J. G. Isebrands, C. A. Mohn, G. C. Stanosz and G. A. TUSKAN (2001): Poplar breeding and testing strategies in the north-central U.S.: Demonstration of potential yield and consideration of future needs. For. Chron. 77 (2): 245-253.

Sidhu, D. S., A. S. Hans and R. S. Dhanda (1990): Poplar Cultivation, Punjab Agricultural University Publication. p. 38.

SIDHu, D. S. and G. P. S. DHILlon (2007): Field performance of ten clones and two sizes of planting stock of Populus deltoides in Indo-gangetic plains of India. New Forest 34 (2): 115-122.

Singh, ARun P., R. S. Bhandari and T. D. VeRMA (2004): Important insect pests of poplars in agroforestry and strategies for their management in northwestern India. Agroforestry Syst. 63: 15-26.

Singh, N. B., D. Kumar, G. S. Rawat, R. K. Gupta, K. Singh and S. S. NEGI (2001): Clonal evaluation on poplar (Populus deltoides Bartr.) in eastern Uttar Pradesh. II Estimates of genetic parameters in field testing. Indian Forester 127 (2): 163-172.

Tewari, S. K., D. Pandey, V. Pandey and S. Tripathi (1994): Inter-character correlation in Populus deltoides Bartr. Ind J For 17: 61-63.

Toky, O. P., R. P. Bisht, N. Kumar and R. R. Singh (1996): Growth variability of Populus deltoides (Marsh.) clones in arid climate of North-Western India. Ind J For 19 (1): 69-73.

WILCOX, J. R. and R. E. JR. FARMER (1967): Variation and inheritance of juvenile characters of eastern cottonwood. Silvae Genetica 16: 162-165.

Zhang, S. Y., Q. Yu, G. Chauret and A. KoubaA (2003): Selection for both growth and wood traits in hybrid poplar clones. Forest Science 49 (6): 1-8. 